\title{
Negocjacje dla odnowy organizacji
}

\section{Negotiations for organizational renewal}

\author{
Andrzej Kozina \\ Uniwersytet Ekonomiczny w Krakowie, e-mail: kozinaa@uek.krakow.pl
}

\begin{abstract}
Streszczenie
Realizacja przedsięwzięć związanych z odnową organizacji wymaga koordynacji zróżnicowanych zadań realizowanych przez jednostki organizacyjne. W trakcie działań usprawniających pojawia się konieczność uzgodnień zakresu, terminów, sposobu realizacji itp. tych działań. Ujawniają się przy tym różne grupy interesu o celach wspólnych i sprzecznych. Pojawia się więc konieczność negocjacji, aby podjąć wspólne decyzje i rozwiązać konflikty. Celem artykułu jest przedstawienie charakterystyki takich negocjacji, niezbędnych do realizacji przedsięwzięć ukierunkowanych na usprawnianie funkcjonowania firmy. We wstępie przedstawiono interpretacje pojęć odnowy organizacji i negocjacji oraz definicję negocjacji dla odnowy organizacji. Następnie scharakteryzowano ich zewnętrzne i wewnętrzne uwarunkowania. Zaprezentowano ich specyficzne cechy i wyodrębniono ich rodzaje. Wreszcie scharakteryzowano konflikty występujące w rozważanych negocjacjach. W podsumowaniu wskazano kierunki dalszych badań.
\end{abstract}

Słowa kluczowe: negocjacje (gospodarcze), odnowa organizacji, pojęcie, uwarunkowania, cechy i rodzaje negocjacji dla odnowy organizacji.

\begin{abstract}
The objective of the paper was to characterize (business) negotiations within organizational renewal process, being one of the types of negotiations conducted in a company. They are necessary from the point of view of the effective implementation of the project focused on organizational performance improvement. In the introduction the general ideas of organizational renewal and negotiations were presented as well as the definition of the considered negotiations was suggested. Then their context was described, i.e. both their external and internal determinants. Afterwards the features of such negotiations were enumerated and their specific types were distinguished. The next part of the paper contains the description of conflicts occurring in the considered negotiations. In the closing part the presented concept is evaluated and the directions of further research are pointed out, focusing on the development of that concept.
\end{abstract}

Keywords: (business) negotiations, organizational renewal, idea, determinants, features and types of negotiations for organizational renewal. 
The most important trip you may take in life is meeting people half way H. Boyle

\section{Wstęp (podstawowe pojęcia)}

W literaturze z zakresu odnowy organizacji problematyka negocjacji jest jedynie wzmiankowana lub omawiana fragmentarycznie. Porusza się niektóre aspekty tych negocjacji, traktując je najczęściej jako jedną z funkcji kierowników projektów lub niezbędnych umiejętności menedżerskich. Stosunkowo rzadko wyodrębnia się kwestę negocjacji jako jedno z istotnych zagadnień $\mathrm{w}$ rozważanym obszarze. $\mathrm{W}$ związku $\mathrm{z}$ tym $\mathrm{w}$ artykule proponuje się kompleksowe ujęcie omawianych negocjacji, możliwe do zastosowania w realizacji praktycznych przedsięwzięć z zakresu odnowy organizacji. Przed przystąpieniem do zasadniczych rozważań celowe jest zdefiniowanie podstawowych pojęć używanych w artykule, tj. odnowy organizacji i negocjacji (w firmie).

Za punkt wyjścia można przyjąć, iż odnowa to zmiana formuły działania organizacji, owocująca rekonstrukcją jej modelu biznesu, przy czym jeżeli proces odnowy organizacyjnej ma być skuteczny, nie może zostać sprowadzony wyłącznie do prostego przeformułowania modelu biznesu (przemodelowania elementów składowych systemu zarządzania), ale musi być rozwiązaniem systemowym (działaniem kompleksowym), obejmującym swoim zasięgiem całą organizację (odnoszącym się do wszystkich wymiarów jej funkcjonowania). Odnowa związana jest z przebudową dotychczasowego rdzenia organizacji [Cyfert 2012; Cyfert, Bełz, Wawrzynek 2014]. Doprecyzowując pojęcie odnowy organizacyjnej, można przyjąć, iż stanowi ono treść, proces i efekt przekształceń kluczowych elementów modelu biznesowego (systemu zarządzania) [Bełz 2012; Cyfert, Bełz, Wawrzynek 2014]. W procesie odnowy organizacyjnej zarządzający dokonują wyboru pomiędzy procesami rewitalizacji, zasadzającymi się na wykorzystaniu dotychczasowych kompetencji bądź nakierowanymi na przemodelowanie kluczowych kompetencji procesami adaptacji [Cyfert 2012]. Podsumowując, można stwierdzić, iż odnowa organizacji oznacza zmianę kompleksową i fundamentalną, ukierunkowaną na podniesienie sprawności działania organizacji.

Jeśli chodzi o ogólne znaczenie pojęcia negocjacji, to w literaturze przedmiotu najczęściej spotyka się następujące ich interpretacje, tzn. traktuje się je jako:

1) proces decyzyjny,

2) metodę kierowania konfliktem i osiągania porozumienia,

3) wzajemną zależność partnerów,

4) proces: komunikowania się, wymiany i tworzenia wartości [Lewicki et al. 2005, s. 17-33; Kozina 2012, s. 21-24; Rządca 2003, s. 23-47].

W rozważanym obszarze najistotniejsza jest pierwsza interpretacja, natomiast pozostałe mają znaczenie uzupełniające. Negocjacje rozumiane jako interakcyjny proces podejmowania decyzji w jego fazie przygotowawczej strony realizują niezależnie od siebie (z punktu widzenia ich celów). Następnie dokonują wzajemnych uzgodnień w zakresie dwóch par zbiorów: wariantów rozwiązań i kryteriów oceny, określonych wstępnie dla każdej ze stron z osobna w efekcie analizy problemu decyzyjnego. Wreszcie strony wybierają kryteria z punktu widzenia ich interesów i ustalają zbiór alternatyw (jako część wspólną wyjściowych opcji).

Negocjacje w przedsiębiorstwie obejmują wszelkie ich rodzaje wynikające z jego istoty jako szczególnego rodzaju organizacji. Stanowią one instrument zarządzania firmą. Bierze się tutaj pod uwagę zarówno te sytuacje, w których firma stanowi środowisko negocjacji, jak i te, dla których jest ich stroną. Negocjacje stanowią więc sposób kształtowania relacji firmy z otoczeniem i wewnętrznych warunków współdziałania [Kozina 2012, s. 48-49].

Biorąc pod uwagę powyższe stwierdzenia, przyjmiemy, iż różnego typu negocjacje występujące w procesie odnowy organizacji (w skrócie; negocjacje dla odnowy organizacji) stanowią specyficzny instrument realizacji wszelkiego rodzaju procesów i projektów w ramach owej odnowy. Tak rozumiane negocjacje mieszczą się bowiem w tzw. warstwie realizacyjnej systemowego modelu organizacji, wspierającej proces jej odnowy i określającej sposoby realizacji działań operacyjnych [Cyfert 2012]. W dalszych rozważaniach zostanie zatem przyjęte założenie, iż zasadniczym punktem odniesienia w opisie i analizie rozważanych negocjacji będzie projekt (proces) odnowy, a ich podmiotem - zespół projektowy (procesowy) odpowiedzialny za realizację tego projektu (procesu), w szczególności szef tego zespołu. Taka interpretacja pozwala na sprecyzowanie miejsca i roli negocjacji w tym procesie oraz określenie uwarunkowań, cech i typów rozważanych negocjacji.

\section{Uwarunkowania negocjacji dla odnowy}

Jeśli chodzi o zewnętrzne uwarunkowania rozważanych negocjacji, to można wyjść od stwierdzenia, iż przedsiębiorstwo jako system otwarty pozostaje we wzajemnych relacjach z otoczeniem oraz dokonuje z nim wymiany materialnej i informacyjnej, która musi być w jakiś sposób zorganizowana, zarówno z punktu widzenia jej celów, jak i przebiegu [Rządca 2003, s. 166]. Określenie otoczenia jako ogółu elementów nienależących do systemu, z którymi pozostaje on w interakcji, jest jednakże zbyt ogólne, trzeba więc rozważyć jego bardziej szczegółowe interpretacje celem identyfikacji kontekstu negocjacji w firmie.

W analizie strategicznej wyróżnia się otoczenie dalsze (makrootoczenie, pośrednie, ogólne) i bliższe (konkurencyjne, bezpośrednie, zadaniowe) - [Gierszewska, Romanowska 2003, s. 34 i nast.]. Dalsze to podmioty, z którymi firma ma pośrednie relacje, oraz procesy i zjawiska, określające warunki jej funkcjonowania i rozwoju. Składa się z subotoczeń: ekonomicznego, technologicznego, politycznego, prawnego, społecznego, kulturowego, demograficznego, przyrodniczego (podział rodzajowy) oraz: krajowego i międzynarodowego (globalnego) - podział ze względu na zasięg. Czynniki tego otoczenia jedynie pośrednio wpływają na negocjacje $\mathrm{w}$ firmie poprzez stwarzanie warunków sprzyjających lub utrudniających realizację przedsięwzięć, których one dotyczą. Stanowią „warunki brzegowe", lecz nie wyjaśniają natury owych negocjacji. Ujawniają się natomiast bezpośrednio i wymagają szczegółowej analizy 
na poziomie konkretnych negocjacji, np. poprzez wpływ zmian w prawie pracy na cele i zakres negocjacji dotyczących zwolnień pracowników, ogólnych trendów rynkowych na siłę przetargową firmy w porównaniu z konkurentami i jej strategię rozwoju, wpływ czynników społecznych na negocjacje w ochronie środowiska itp. Dla poszczególnych negocjacji istotne jest więc rozpatrywanie ich subotoczeń celem uwzględnienia specyficznych uwarunkowań, zgodnie z podejściem sytuacyjnym [Bielski 2004, s. 25-27]. Zdarza się, iż potencjalnie „dalsze” uwarunkowania, np. nowe przepisy prawne czy niestabilność gospodarcza, mogą mieć znacznie większy wpływ niż „bliższe” czynniki, np. w rutynowych negocjacjach między stałymi partnerami.

Otoczenie bliższe odgrywa znacznie większa rolę dla negocjacji w firmie, gdyż stanowią je podmioty, z którymi jest ona w bezpośrednich stosunkach kooperacyjnych lub konkurencyjnych (poprzez sprzężenia zwrotne). Są to zatem dostawcy niezbędnych zasobów (materiałów, surowców, półfabrykatów, usług, wyposażenia, środków finansowych, informacji) oraz nabywcy (odbiorcy, klienci) wyrobów (usług). Negocjacje stanowią bowiem środek wywierania przez firmę wpływu na otoczenie bliższe.

M. Bielski [2004, s. 78-80], podkreślając, iż granice między otoczeniem bezpośrednim i ogólnym nie rysują się dostatecznie ostro, stwierdza, iż pierwsze jest indywidualne, inne dla każdej organizacji, drugie - wspólne dla wielu organizacji. Drugie opisuje podobnie jak stwierdzono powyżej, natomiast do pierwszego zalicza także instytucje państwowe i samorządowe, lokalny rynek pracy, czynniki społeczne: związki zawodowe, samorząd gospodarczy, postawy społeczeństwa i jego oczekiwania w stosunku do organizacji, a także czynniki techniczne. Koncepcja ta lepiej określa zakres i uwarunkowania sytuacji negocjacyjnych w firmie, gdyż jej otoczenie jest zdefiniowane w specyficzny sposób.

$\mathrm{Z}$ uwagi na relatywizm typologii otoczenia, najodpowiedniejszym (do celów badań) sposobem jego definiowania jest użycie teorii kontraktowej [Alchian, Demsetz 1972], w ramach której wyróżnia się jego dwa rodzaje: kontraktowe - wszystkie podmioty, które posiadają z firmą bezpośrednie relacje kontraktowe (jawne i niejawne), oraz kontekstowe - obejmuje czynniki determinujące jej działania bez wchodzenia z nią w relacje kontraktowe.

Obecnie ma miejsce znaczna dynamika, złożoność i nieprzewidywalność wpływu otoczenia. Bywa ono określane jako burzliwe lub turbulentne. Powoduje różnicowanie się przypadków negocjacyjnych, utrudniając ich opis i analizę. Wszędzie odczuwana jest konieczność kooperacji. W skali globalnej kooperacja staje się kluczem do przeżycia gatunku ludzkiego. Współpraca nie oznacza końca konkurencji. Drogą od konkurencji do kooperacji są negocjacje [Ury 1995, s. 16-17]. Wszystkie przedsiębiorstwa funkcjonują dziś w skomplikowanej sieci powiązań, które tworzą się, nitka za nitką, w toku negocjacji [Ertel 2005]. Rozwijają się dwie pośrednie formy współdziałania, dające lepsze efekty od uzyskiwanych poprzez działania niezależne, tzn. koopetycja, polegająca na jednoczesnym współdziałaniu i konkurowaniu podmiotów gospodarczych [Brandenburger, Nalebuff 1997] oraz koewolucja, inaczej „wspólny rozwój" [Eisenhardt, Galunic 2000].
Konkurenci nie są partnerami negocjacyjnymi firmy, lecz stanowią istotny punkt odniesienia $\mathrm{w}$ analizie przednegocjacyjnej, zwłaszcza dla oceny siły przetargowej i wyboru alternatywnych działań w relacjach z innymi podmiotami. W przypadku dostawców i odbiorców, pomimo istnienia także konkurencyjnych interesów w relacji do celów firmy, współpraca jest główną przesłanką rozważanych negocjacji. Najogólniej kooperacja (zewnętrzna) to współdziałanie (wspomaganie się) wielu podmiotów dla osiągnięcia wspólnego celu. W szerokim znaczeniu jest to współpraca przy wytwarzaniu wyrobów i świadczeniu usług, czyli obejmuje wszystkie rodzaje związków między firmami, również w zakresie zaopatrzenia materiałowo-technicznego i innych funkcji pomocniczych. Ścisłe znaczenie (kooperacja właściwa) to bezpośrednia współpraca wyspecjalizowanych podmiotów, między którymi występują przepływy elementów kooperacyjnych i świadczenie usług, wykonywane na specjalne zamówienie odbiorcy z przeznaczeniem do określonego wyrobu gotowego [Famielec 1992, s. 9].

Problemy współdziałania można rozpatrywać z szerszej perspektywy teorii relacji międzyorganizacyjnych, stanowiącej dogodniejszą płaszczyznę analizy uwarunkowań negocjacji niż tradycyjna analiza powiązań firmy z otoczeniem i obejmującej różne formy współpracy gospodarczej, np. wspólne przedsięwzięcia, sieci i konsorcja, alianse, porozumienia handlowe itp. [Ring, van de Ven 1994; Barringer, Harrison 2000]. Relacje te obejmują względnie trwałe transakcje, przepływy zasobów i informacji oraz inne kontakty, które powstają między organizacjami oraz pomiędzy firmą i otoczeniem. Są to bardziej uporządkowane i trwałe formy od realizowanych jedynie poprzez działanie mechanizmów rynkowych. Można je opisywać za pomocą takich cech, jak: częstotliwość kontaktów, korzyści ze współpracy, stopień sformalizowania relacji, pośredni i bezpośredni wpływ innych organizacji, zbieżność celów. Omawiane formy współpracy są podstawą wyodrębnienia typów negocjacji zewnętrznych, a co za tym idzie, wyznaczenia ich celów i zakresu. Rolę negocjacji z punktu widzenia omawianych relacji opisano w pracy [Ring, van de Ven 1994], gdzie rozpatruje się je jako jeden z trzech etapów w procesie kształtowania powiązań kooperacyjnych (inne to: podejmowanie i realizacja wzajemnych zobowiązań; etapy te powtarzają się cyklicznie, a integruje je ocena efektywności współdziałania). W etapie tym strony formułują wspólne oczekiwania dotyczące ich motywów do współdziałania, zakresu inwestycji we współpracę i dostrzeganych czynników niepewności w realizacji wspólnego projektu. Kładzie się nacisk na formalne procesy targowania się, odpowiednie zachowania przy doborze i sposobie traktowania partnera oraz wzajemne przekonywanie się i spieranie co do warunków i procedur współpracy.

Jeśli chodzi o wewnętrzne uwarunkowania rozważanych negocjacji, tj. mające swoje źródło w organizacji, to podstawą ich analizy również jest współistnienie kooperacji i konkurencji, określających wzajemne interakcje pomiędzy elementami organizacji, będące podłożem negocjacji. Znacznie większa (niż dla powiązań zewnętrznych) jest jednak liczba i intensywność wzajemnych interakcji w ramach szeregu potencjal- 
Tabela 1. Wewnętrzne uwarunkowania negocjacji dla odnowy organizacji

\begin{tabular}{|c|c|c|}
\hline Cechy & Wymiar kooperacji (współpraca) & Wymiar konkurencji (konflikt) \\
\hline Cele & $\begin{array}{l}\text { Formułowanie i uzgadnianie celów (adekwatnie do możliwości } \\
\text { i wymagań otoczenia) oraz ich dekompozycja (agregacja) i ustalanie } \\
\text { priorytetów }\end{array}$ & $\begin{array}{l}\text { Rozbieżności celów elementów i całości oraz pomiędzy } \\
\text { celami elementów, odmienność priorytetów i niezgodnośc } \\
\text { celów z potrzebami otoczenia }\end{array}$ \\
\hline $\begin{array}{l}\text { Zadania } \\
\text { i funkcje }\end{array}$ & $\begin{array}{l}\text { Ustalanie zadań i funkcji (w wyniku dekompozycji celów) oraz } \\
\text { projektowanie i uzgadnianie procesów realizacji zadań. }\end{array}$ & $\begin{array}{l}\text { Zbytnia szczegółowość (ogólność) zadań, niezgodność } \\
\text { funkcji z celami oraz związane z tym problemy ich } \\
\text { realizacji. }\end{array}$ \\
\hline $\begin{array}{l}\text { Zasoby } \\
\text { ludzkie }\end{array}$ & $\begin{array}{l}\text { Dobór wykonawców adekwatnie do zadań i ustalanie zakresów ich } \\
\text { działania (przydział zadań i odpowiedzialności). }\end{array}$ & $\begin{array}{l}\text { Wzajemne niedostosowanie ludzi i zadań, niezadowolenie } \\
\text { z roli, asymetryczność (polaryzacja) funkcji (ról) } \\
\text { organizacyjnych }\end{array}$ \\
\hline $\begin{array}{l}\text { Zasoby } \\
\text { rzeczowe }\end{array}$ & $\begin{array}{l}\text { Przydzielanie zasobów w ilości } \\
\text { i jakości dostosowanej do realizowanych zadań i funkcji, } \\
\text { bilansowanie ich wykorzystania }\end{array}$ & $\begin{array}{l}\text { Ograniczoność lub niedostępność (wspólnych) zasobów, } \\
\text { dążenie do ich pozyskania lub zwiększenia kosztem innych } \\
\text { jednostek. }\end{array}$ \\
\hline $\begin{array}{l}\text { Grupowanie } \\
\text { elementów }\end{array}$ & $\begin{array}{l}\text { Dobór kryteriów rozczłonkowania firmy, adekwatnych do } \\
\text { realizowanych zadań i funkcji, oraz projektowanie organizacji } \\
\text { wewnętrznej zespołów }\end{array}$ & $\begin{array}{l}\text { Użycie niewłaściwych kryteriów grupowania, powodujące } \\
\text { dublowanie, nierealizowanie lub niepełne realizowanie } \\
\text { zadań oraz nadmierne zróżnicowanie i niezgodności } \\
\text { statusów zespołów }\end{array}$ \\
\hline $\begin{array}{l}\text { Zależności } \\
\text { funkcjonalne }\end{array}$ & $\begin{array}{l}\text { Ustalenie zasad współdziałania, koordynacja realizacji zadań } \\
\text { oraz projektowanie niezbędnych procesów komunikacyjnych }\end{array}$ & $\begin{array}{l}\text { Współzależność działań, niesprawne środki koordynacji } \\
\text { i problemy komunikacyjne (braki, opóźnienia, zła jakość } \\
\text { itp. danych) - konflikty poziome }\end{array}$ \\
\hline $\begin{array}{l}\text { Zależności } \\
\text { hierarchiczne }\end{array}$ & $\begin{array}{l}\text { Preferowany styl kierowania } \\
\text { i ustalenie relacji nadrzędności -podległości }\end{array}$ & $\begin{array}{l}\text { Napięcia w relacjach przełożony-podwładny (konflikty } \\
\text { pionowe) }\end{array}$ \\
\hline $\begin{array}{l}\text { Uprawnienia } \\
\text { decyzyjne }\end{array}$ & $\begin{array}{l}\text { Podział, sprecyzowanie i rozmieszczenie uprawnień, adekwatnie } \\
\text { do zleconych zadań i odpowiedzialności }\end{array}$ & $\begin{array}{l}\text { Naciski i ograniczenia z powodu nadmiernej } \\
\text { (de)centralizacji uprawnień, niejednoznaczności i/lub zbyt } \\
\text { wąskie (szerokie) uprawnienia, powodujące spory } \\
\text { kompetencyjne między kierownikami }\end{array}$ \\
\hline $\begin{array}{l}\text { Formalizacja } \\
\text { działań }\end{array}$ & $\begin{array}{l}\text { Opracowywanie przepisów (regulaminów, procedur, zasad, } \\
\text { wytycznych itp.) warunkujących sprawną realizację zadań }\end{array}$ & $\begin{array}{l}\text { Problemy wynikające z niedostatecznego (za duża swoboda } \\
\text { działania) lub nadmiernego (rygorystyczność) stopnia } \\
\text { formalizacji, utrudniającego realizację zadań }\end{array}$ \\
\hline
\end{tabular}

Źródło: opracowanie własne.

nych i faktycznych współzależności, które stwarza struktura firmy. Konieczność wzajemnego współdziałania i związane z nim procesy wymiany i koordynacji działań, niezbędne do osiągnięcia założonych celów przez dany zespół ludzi, stanowią decydujące przesłanki negocjacji. Nasilenie tych interakcji powoduje także szereg rozbieżności interesów, wynikających z odmiennych celów, tj. powstawanie konfliktów organizacyjnych. Wynikają one z istoty firmy jako szczególnego rodzaju organizacji, są naturalną konsekwencją jej istnienia [Greenhalgh 1986].

Ogólny schemat metodyczny badania tych uwarunkowań stanowi identyfikacja form relacji pomiędzy interesariuszami wewnętrznymi. Nie jest to jednak ujęcie wystarczające, gdyż nie obejmuje pierwotnych przyczyn i faktycznej natury rozważanych uwarunkowań. Do ich dokładnego opisu i analizy niezbędne jest przyjęcie zbioru istotnych charakterystyk, opisujących organizację firmy, np. R. Rządca [2003, s. 173 i nast.], analizując negocjacje jako zmienną zależną, rozważa trzy zmienne niezależne: strukturę, strategię i kulturę organizacyjną. Struktura organizacyjna (a zwłaszcza zależności) to główna determinanta procesów kooperacji wewnętrznej. Negocjacje są naturalnym sposobem organizowania funkcjonowania każdej organizacji, a budowanie struktury z kolei można potraktować jako proces utrwalania wynegocjowanych porozumień, a więc także zastępowania negocjacji rozwiązaniami in- stytucjonalnymi [Rządca 2003, s. 171]. Należy zatem uwzględnić funkcje tej struktury [Nalepka, Kozina 2007, s. 20 i nast.]. Uwzględniając powyższe stwierdzenia, opracowano typologię wewnętrznych uwarunkowań negocjacji w firmie (tab. 1).

\section{Specyficzne cechy negocjacji dla odnowy organizacji}

Określając miejsce i rolę negocjacji w ramach projektów odnowy, można wyjść od tezy, iż jedną z cech zarządzania projektami jest to, iż ich realizacja, a zwłaszcza wdrażanie, wymaga umiejętności negocjacji i rozwiązywania konfliktów.

Poniżej zestawiono najważniejsze, szeroko rozumiane cechy rozważanych negocjacji, biorąc pod uwagę ich wstępną interpretację i uwarunkowania, przedstawione powyżej. Zestawienie takie jest niezbędne do wyczerpującego odzwierciedlenia ich specyfiki w porównaniu z innymi typami negocjacji w firmie.

1. Oprócz samego projektu (procesu) odnowy (jak wspomniano, jest to zasadniczy punkt odniesienia w opisie i analizie rozważanych negocjacji) oraz strategii rozwoju firmy jako kluczowego elementu ich kontekstu, przy rozpatrywaniu tych negocjacji należy uwzględnić trzy istotne wymiary (aspekty): zespół realizujący projekt odnowy 
(zadaniowy, wirtualny), czyli ich kluczowy podmiot, przedsiębiorstwo (bezpośrednie środowisko) oraz otoczenie zewnętrzne (bliższe i dalsze).

2. Cele i zakres przedmiotowy (problemy) negocjacji są ściśle wyznaczone przez koncepcję realizowanego projektu odnowy, w tym jego rodzaj, potrzeby klienta (wewnętrznego i zewnętrznego), cele i zamierzenia, zakres przedmiotowy, zasoby, czas realizacji itp.

3. Zgodnie z ogólną interpretacją miejsca i roli negocjacji w procesie zarządzania firmą, w rozważanym obszarze należy je traktować jako instrument zarządzania projektami ukierunkowanymi na odnowę organizacji (element jego instrumentalnego aspektu).

4. Rozważane negocjacje stanowią jeden z najbardziej kompleksowych i złożonych rodzajów negocjacji w przedsiębiorstwie, gdyż jeśli wziąć pod uwagę szeroki i interdyscyplinarny zakres projektów odnowy, to de facto występuje tutaj szereg różnorodnych sytuacji negocjacyjnych, typowych dla dziedzin funkcjonalnych, np. handlowych, finansowych, pracowniczych itp.

5. Zakres tych negocjacji (poszczególnych przypadków) jest zatem stosunkowo szeroki - dotyczą zwykle wielu różnorodnych zagadnień, objętych zakresem projektu, w praktyce rzadko mogą odnosić się do jednej kwestii - stanowią wtedy część szerszych negocjacji, np. dotrzymania terminu dostawy w ramach interwencji mającej zapobiec ewentualnemu opóźnieniu w realizacji projektu.

6. Z przyjętej interpretacji procesu odnowy organizacji wynika, iż rozważane negocjacje mogą mieć charakter negocjacji zarówno operacyjnych czy taktycznych, np. dotyczących rozwoju produktu, czy odcinkowych przedsięwzięć inwestycyjnych, jak i strategicznych, np. restrukturyzacji funkcjonalnej czy kompleksowej modernizacji systemu informacyjnego (w zależności od specyfiki realizowanych przedsięwzięć usprawniających).

7. Stronami (uczestnikami) negocjacji są wszyscy interesariusze projektu odnowy, czyli wszelkie osoby, grupy lub organizacje, które są związane z jego realizacją, tj. albo bezpośrednio zaangażowane w projekt lub w których interesie może być pozytywne lub negatywne wpływanie na jego realizację i efekty (interesariuszy scharakteryzowano w kolejnym punkcie) [Kozina 2012, s. 86-90]. Zespół projektowy (jego kierownictwo) musi zatem zidentyfikować interesariuszy oraz określić ich potrzeby, wymagania i oczekiwania.

8. Przy występowaniu wielu interesariuszy (zwłaszcza przy złożonych projektach) rozważane negocjacje mają charakter wielostronny. Dodatkowo przy znacznym ich zróżnicowaniu, realizacja danego projektu może przynieść wiele sytuacji negocjacyjnych, tj. prowadzonych w różnych konfiguracjach interesariuszy projektu. Wymaga to doboru odpowiednich strategii, zwłaszcza zawierania koalicji z niektórymi interesariuszami, warunkujących sprawną realizację projektu [Kozina 2012, s. 91-95].

9. Analiza przednegocjacyjna (sytuacji negocjacyjnej) musi zatem obejmować zarówno wymienione wyżej wymiary negocjacji oraz cele i wymagania interesariuszy projektu, jak i relacje oraz zależności pomiędzy nimi, zwłaszcza w układzie: zespół projektowy - jego otoczenie, a także wewnątrz tego zespołu.

10. Wymiar kooperacji w rozważanych negocjacjach obejmuje wszelkie uzgodnienia pomiędzy interesariuszami projektu odnowy, warunkujące jego efektywną realizację, a punktem odniesienia przy poszukiwaniu integrujących rozwiązań są wspólne korzyści, możliwe do osiągnięcia w wyniku pomyślnego zakończenia realizacji projektu.

11. Wymiar konkurencji w omawianych negocjacjach sprowadza się natomiast do współzawodnictwa pomiędzy interesariuszami, wynikającego z rozbieżności ich celów, realizowania odmiennych funkcji, występowania ograniczonych zasobów, realizowania projektów konkurencyjnych, napięć czasowych itp.

12. Z uwagi na wzmiankowaną złożoność rozważanych negocjacji, procesy podejmowania decyzji w ich ramach mają charakter wielokryterialny, wielowariantowy i wielopodmiotowy, uwzględniający cele interesariuszy projektu. Decyzje te dotyczą zarówno samej koncepcji procesu odnowy (celów, rodzaju, zakresu itp.), jak i sposobu jego realizacji (zasobów, terminów realizacji, zasad wdrażania itp.). Przesłanki oceny samych negocjacji wynikają wprost z parametrów (kryteriów oceny) projektu odnowy, a zwłaszcza czasu, jakości i kosztów (negocjacje muszą zapewniać realizację przyjętych standardów).

13. Negocjacje dla odnowy organizacji posiadają wszystkie cechy typowego projektu, co wynika z ich narzędziowego charakteru. W większości mają charakter niepowtarzalny (jednorazowy), są trudne do ustrukturalizowania, aczkolwiek mogą również dotyczyć rutynowych przedsięwzięć usprawniających, np. dotyczących oszczędności wydatków czy powtarzalnych działań, np. przygotowawczych lub szkoleniowych.

14. Omawiane negocjacje występują we wszystkich fazach realizacji projektu odnowy, przy czym na etapie jego przygotowania są niezbędne do stworzenia odpowiednich warunków i zaleceń realizacyjnych, w fazie wykonawczej - zapewnienia ich przestrzegania w konfrontacji z ustalonymi standardami, w fazie zakończenia - przyjęcia i wdrożenia efektów projektu, tj. spełnienia tych standardów.

15. Z uwagi na różnorodność rozważanych negocjacji bardzo istotnym i trudnym problemem jest identyfikacja i analiza wielu zróżnicowanych, wzajemnych związków pomiędzy poszczególnymi sytuacjami negocjacyjnymi, zarówno dotyczącymi danego projektu odnowy, jak i w odniesieniu do innych zadań i przedsięwzięć w organizacji. W efekcie występuje konieczność ciągłej i pełnej koordynacji tych negocjacji, zwłaszcza w razie występowania powiązań o charakterze konfliktowym. Ponadto ich sprawna realizacji wymaga efektywnej komunikacji pomiędzy interesariuszami projektu.

16. Procesy wzajemnej wymiany i wspólnego tworzenia wartości w ramach negocjacji dla odnowy organizacji dotyczą zarówno pozyskiwania i alokacji zasobów rzeczowych i finansowych, jak i (niekiedy przede wszystkim) wartości niematerialnych, tj. wiedzy, idei, pomysłów, koncepcji itp.

17. Za realizację omawianych negocjacji odpowiada kierownik projektu odnowy (koordynator, grupa kierująca itp.) 
lub upoważnieni przez niego członkowie zespołu albo liderzy podzespołów (podprojektów) jako reprezentanci zespołu - jest to związane $\mathrm{z}$ aspektem kierowania zespołem projektowym [Pawlak 2006, s. 204 i nast.; Trocki, Grucza, Ogonek 2003, s. 113-115].

18. Ze względu na specyfikę zarządzania projektami, a zwłaszcza znaczenie i wagę celów interesariuszy, negocjacje powinny być prowadzone przez kierownika zespołu odnowy jako reprezentanta przede wszystkim interesów klienta projektu, niemniej jednak przy rozstrzyganiu ewentualnych konfliktów musi on brać pod uwagę cele pozostałych interesariuszy (ich osiąganie warunkuje realizację zamierzeń projektu także z punktu widzenia klienta).

19. W skład ewentualnych zespołów negocjacyjnych mogą wchodzić wszyscy lub niektórzy członkowie zespołu projektowego oraz eksperci zewnętrzni, np. doradcy funkcjonalni (sztabowcy) zatrudnieni w firmie lub konsultanci spoza firmy.

20. Niektóre negocjacje mogą być realizowane poza zespołem projektowym, bez udziału jego członków i/lub przy konsultacji z jego kierownictwem, tj. na poziomie firmy, głównie w dwóch przypadkach:

- ustalania zasad i warunków realizacji zlecenia (oraz dokonywania odbioru prac) przez kierownictwo naczelne firmy ze zleceniodawcą zewnętrznym (w imieniu zespołu lub nawet przed jego powołaniem),

- gdy jednostki organizacyjne spełniają funkcje pomocnicze, zwłaszcza związane z zapewnieniem niezbędnych zasobów i świadczeniem usług w odniesieniu do wielu (pod)projektów odnowy realizowanych w firmie (funkcje te są scentralizowane).

21. Realizacja różnorodnych negocjacji w zarządzaniu projektem odnowy prowadzi w efekcie do zawierania szeregu kontraktów (formalnych i niepisanych) pomiędzy interesariuszami projektu, w całym cyklu jego realizacji.

22. Z powyższych stwierdzeń wynika, iż rozważane negocjacje stanowią istotny aspekt zarządzania zasobami ludzkimi $\mathrm{w}$ ramach kierowania projektami odnowy, przede wszystkim wymagane jest angażowanie pracowników posiadających odpowiednie kompetencje w zakresie negocjacji i rozwiązywania konfliktów.

Podsumowując: w porównaniu z innymi ich rodzajami, negocjacje w zarządzaniu projektami odnowy mają kompleksowy (złożony) i wielowymiarowy (wieloaspektowy) charakter, przenikając niejako inne typowe sytuacje negocjacyjne. Niezbędne jest zatem stosowanie różnorodnych narzędzi szczegółowych, a zwłaszcza identyfikacji i analizy przednegocjacyjnej, sprzężonych z tradycyjnymi instrumentami zarządzania projektami. Powoduje to konieczność istotnego poszerzenia zakresu zadań i wzbogacenia potencjału wykonawców i kierownictwa projektów odnowy.

\section{Rodzaje negocjacji dla odnowy organizacji}

Przyjęte będzie założenie, iż rodzaje rozważanych negocjacji należy rozważać z punktu widzenia kierownictwa zespołu projektowego jako kluczowego interesariusza (partnera innych grup interesów), zgodnie z ogólną interpretacją zarządzania projektami.
Intuicyjnym kryterium wyróżniania rodzajów negocjacji dla odnowy organizacji jest struktura procesu realizacji projektu odnowy, tj. fazy jego: przygotowania, realizacji i zakończenia, gdyż negocjacje stanowią narzędzie osiągnięcia celów tych faz. Zasadniczą przesłanką różnicowania rozważanych negocjacji powinno być jednak środowisko, w którym się one odbywają, co pozwala na wyodrębnienie ich dwóch zasadniczych typów:

1) zewnętrzne, tzn. odbywające się poza zespołem projektowym, pomiędzy jego kierownikiem a innymi interesariuszami, w relacjach pomiędzy zespołem a środowiskiem wewnętrznym (w firmie) i zewnętrznym (z podmiotami spoza firmy),

2) wewnętrzne, tj. mające miejsce w zespole projektowym, pomiędzy kierownikiem (koordynatorem) projektu odnowy a jego wykonawcami (członkami zespołu).

Uszczegółowieniem negocjacji pierwszego rodzaju jest wskazanie ich podtypów, tj. poszczególnych sytuacji negocjacyjnych ze względu na możliwych partnerów kierownictwa projektu odnowy, tj. najważniejszych spośród wymienionych wcześniej jego interesariuszy.

Kluczowymi interesariuszami projektu, tworzącymi jego specyficzne środowisko, są następujące podmioty.

1. Organizacja realizująca (macierzysta) - firma, której pracownicy są bezpośrednio zatrudnieni lub współdziałają przy pracach projektowych, w drodze do osiągnięcia celów zgodnie z zamierzeniami firmy oraz przy wykorzystaniu przydzielonych zasobów (zarząd lub przełożony z firmy macierzystej jako wewnętrzny klient projektu).

2. Klient (zleceniodawca zewnętrzny) - organizacja lub osoba, która zleca realizację projektu i jest jego użytkownikiem, odbiorcą jego wytworów. W przypadku projektów odnowy jest to zwykle dana organizacja podlegająca odnowie (odgrywa więc podwójną rolę).

3. Kierownik (kierownictwo) projektu (menedżer, koordynator projektu lub grupa zarządzająca czy koordynująca) odpowiedzialny za zarządzanie projektem odnowy (planowanie, organizowanie, motywowanie i kontrolowanie w zespole). Mogą być także powołani liderzy projektów cząstkowych (podprojektów czy subprocesów).

4. Zespół projektowy, odpowiedzialny za jego realizację, powołany spośród pracowników firmy i/lub pochodzących z zewnątrz, czyli wykonawcy projektu.

5. Ewentualnie powołane dodatkowo zespoły:

- merytoryczny, wspomagający zespół projektowy poprzez fachowe doradztwo,

- monitorujący (kontrolny), bieżąco nadzorujący realizacje projektu.

6. Menedżerowie funkcjonalni $\mathrm{w}$ firmie macierzystej, kontrolujący zasoby i nadzorujący członków zespołu w jednostkach macierzystych, przed i po jego powołaniu.

7. Szefowie innych projektów, realizowanych w danej organizacji, powiązanych ze sobą i wymagających koordynacji w ramach przedsięwzięć o szerszym zakresie, tj. przy realizacji szeregu podprojektów (subprocesów) odnowy.

8. Pracownicy funkcjonalni (sztabowi) - wspomagający zespół projektowy w realizacji zadań, tj. pełniący funkcje ekspertów wewnętrznych. 
9. Zewnętrzni dostawcy zasobów niezbędnych do realizacji projektu, w tym:

- inne firmy delegujące pracowników lub zasoby ludzkie z rynku pracy,

- $\quad$ sponsorzy, banki, inwestorzy, dostarczający środków finansowych,

- dostawcy środków rzeczowych (usług, materiałów i wyposażenia),

- $\quad$ konsultanci i eksperci, zapewniający specjalistyczną informację i wiedzę. W najszerszym ujęciu może występować także szereg specyficznych interesariuszy projektu odnowy, luźniej z nim powiązanych, takich jak np. władze lokalne, stowarzyszenia, partie, rządy itp. Spełnianie oczekiwań tych grup interesów może być trudne z powodu rozbieżnych czy zupełnie odmiennych celów, co często prowadzi do konfliktów.

Liczba podmiotów zaangażowanych w ewentualne negocjacje, ich zadania, zakres zasady udziału itp. zależą od specyfiki konkretnego projektu odnowy, tj. jego celów, stopnia złożoności, zakresu itp. Analiza interesariuszy jest zatem niezbędnym działaniem $\mathrm{w}$ fazie przygotowania projektu [Elias, Cavana,
Jackson 2002; McManus, Schlumberger 2002]. Istotne jest zróżnicowanie interesariuszy ze względu na relacje (wpływy) i świadczenia na rzecz i od zespołu projektowego. Charakterystyka sytuacji negocjacyjnych wyodrębnionych na podstawie powyższego zestawienia interesariuszy projektu (partnerów negocjacyjnych jego kierownika) zawiera tab. 2, w której opisano dwie najważniejsze cechy tych sytuacji, tj. ich cele (w zarządzaniu projektem odnowy) i zakres przedmiotowy.

Dynamiczny charakter projektów odnowy sprawia, że kolejne kwestie objęte negocjacjami z poszczególnymi udziałowcami projektu mogą być poruszane kilkakrotnie, może zachodzić konieczność renegocjacji wcześniejszych ustaleń, ich uszczegółowienia czy rozszerzenia, np. przy konieczności pozyskania dodatkowych zasobów w trakcie realizacji projektu czy uzgodnień dotyczących zmiany terminu jego realizacji. Niezbędne może być także podejmowanie ewentualnych rokowań dodatkowych przy wystąpieniu roszczeń spornych, a nawet poszukiwanie nowych partnerów, sporządzanie aneksów do umów itp.

Jeśli chodzi o negocjacje wewnątrz zespołu projektowego, to dotyczą one głównie działań koordynacyjnych, zmierzających

Tabela 2. Charakterystyka negocjacji zewnętrznych w zarządzaniu projektami odnowy

\begin{tabular}{|c|c|c|}
\hline $\begin{array}{c}\text { Interesariusze } \\
\text { zewnętrzni }\end{array}$ & Cele negocjacji & Zakres przedmiotowy negocjacji \\
\hline \multirow[t]{2}{*}{ Klient } & $\begin{array}{l}\text { Ustalenie wymagań i oczekiwań związanych } \\
\text { z realizacją projektu oraz sprecyzowanie } \\
\text { podstawowych warunków i zasad jego wykonania, } \\
\text { w efekcie podjęcie decyzji o jego zainicjowaniu }\end{array}$ & $\begin{array}{l}\text { Cele i zakres przedsięwzięcia oraz standardy jego realizacji, w tym } \\
\text { zwłaszcza dotyczące efektów (wytworów), ram czasowych, niezbędnych } \\
\text { zasobów, wymagań jakościowych oraz kosztorysu (ceny), a także możliwości } \\
\text { i ograniczeń realizacyjnych - uzgadniane, a potem weryfikowane } \\
\text { i potwierdzane ostatecznie przez kierownika ze zleceniodawcą }\end{array}$ \\
\hline & $\begin{array}{l}\text { Zatrudnienie kierownictwa projektu poprzez } \\
\text { uzgodnienie warunków i zawarcie kontraktu na } \\
\text { realizację projektu }\end{array}$ & $\begin{array}{l}\text { Zakres udziału, cele, zadania (funkcje), terminy, wynagrodzenie, zasady: } \\
\text { realizacji działań, współdziałania, raportowania, oceny i wynagradzania, } \\
\text { inne warunki dodatkowe kontraktu oraz realizacja i ocena tych ustaleń }\end{array}$ \\
\hline $\begin{array}{l}\text { Potencjalni } \\
\text { członkowie } \\
\text { zespołu }\end{array}$ & $\begin{array}{l}\text { Zatrudnienie członków zespołu (wykonawców } \\
\text { projektu) poprzez uzgodnienie warunków } \\
\text { i zawarcie kontraktu na realizację projektu }\end{array}$ & $\begin{array}{l}\text { Zakres udziału, cele, zadania (funkcje), terminy, zasady: realizacji działań, } \\
\text { współdziałania, oceny i wynagradzania, raportowania, inne warunki } \\
\text { dodatkowe kontraktu, realizacja i ocena tych ustaleń }\end{array}$ \\
\hline $\begin{array}{l}\text { Dostawcy } \\
\text { zasobów } \\
\text { rzeczowych }\end{array}$ & $\begin{array}{l}\text { Zapewnienie pełnego i terminowego zaspokojenia } \\
\text { potrzeb projektu w zakresie zasobów rzeczowych, } \\
\text { niezbędnych do realizacji projektu poprzez } \\
\text { zawarcie i wykonanie odpowiedniej umowy } \\
\text { handlowej }\end{array}$ & $\begin{array}{l}\text { Ilość (wielkość, zakres), rodzaje (asortyment), ceny (koszty), terminy } \\
\text { i formy płatności, czas i sposób dostarczenia, parametry techniczne, } \\
\text { wymagania jakościowe, warunki odbioru, ustalenia gwarancyjne, zasady } \\
\text { reklamacji i inne warunki umowy na dostawę materiałów, wyposażenia } \\
\text { i usług }\end{array}$ \\
\hline Sponsorzy & $\begin{array}{l}\text { Zapewnienie pełnego i terminowego zaspokojenia } \\
\text { potrzeb projektu w zakresie środków finansowych, } \\
\text { niezbędnych do realizacji projektu poprzez } \\
\text { zawarcie i wykonanie odpowiedniej umowy } \\
\text { (kredytowej sponsoringowej itp.) }\end{array}$ & $\begin{array}{l}\text { Wielkość (wartość) oraz formy, zasady i terminy dostarczenia środków } \\
\text { finansowych, a także ustalenia dotyczące ewentualnej spłaty zobowiązań } \\
\text { (rat, odsetek itp.), udziału w efektach projektu, ewentualnie uzupełniających } \\
\text { świadczeń wymiennych (np. działań promocyjnych, ulg podatkowych, } \\
\text { dodatkowych usług itp.) }\end{array}$ \\
\hline Doradcy & $\begin{array}{l}\text { Zapewnienie pełnego i terminowego zaspokojenia } \\
\text { potrzeb projektu w zakresie fachowego doradztwa, } \\
\text { niezbędnego do realizacji projektu poprzez } \\
\text { zawarcie i wykonanie odpowiedniej umowy na } \\
\text { świadczenie usług }\end{array}$ & $\begin{array}{l}\text { Zakres funkcjonalny i terminy realizacji usług, oraz koszty (cena), zasady } \\
\text { współpracy, sposób realizacji i warunki odbioru prac i inne uzgodnienia } \\
\text { i działania koordynacyjne (tworzenie podzespołów, zebrania i narady, } \\
\text { monitowanie i interwencje, wymiana informacji itp.) z kierownikami innych } \\
\text { projektów i podwykonawcami projektów cząstkowych }\end{array}$ \\
\hline $\begin{array}{l}\text { Kierownicy } \\
\text { innych } \\
\text { (pod)projektów } \\
\text { (subprocesów) }\end{array}$ & $\begin{array}{l}\text { Zapewnienie sprawnego współdziałania oraz } \\
\text { spójności, kompletności i efektywności wszystkich } \\
\text { realizowanych w firmie projektów, z punktu } \\
\text { widzenia osiągania jej celów strategicznych } \\
\end{array}$ & $\begin{array}{l}\text { Cele (cząstkowe i pośrednie) i priorytety, rodzaje podejmowanych działań, } \\
\text { mechanizmy koordynacji, zasady: alokacji zasobów, wzajemnej wymiany } \\
\text { (kooperacji wewnętrznej), komunikowania się, ewentualnej wymienności } \\
\text { funkcji i środków, przemieszczeń pracowniczych, wymiany danych itp. }\end{array}$ \\
\hline Podwykonawcy & $\begin{array}{l}\text { Ustalenie zasad współdziałania przy realizacji } \\
\text { działań cząstkowych (podprocesów), } \\
\text { umożliwiających efektywną realizację projektu } \\
\text { poprzez zawarcie i wykonanie odpowiednich } \\
\text { umów kooperacyjnych }\end{array}$ & $\begin{array}{l}\text { Zakres wzajemnych świadczeń, czas realizacji działań cząstkowych, koszty, } \\
\text { harmonogramy, warunki odbioru prac oraz inne uzgodnienia i działania } \\
\text { koordynacyjne (tworzenie podzespołów, zebrania i narady, monitowanie } \\
\text { i interwencje, wymiana informacji itp.) }\end{array}$ \\
\hline
\end{tabular}

Źródło: opracowanie własne. 
do zapewnienia zbieżności wysiłków indywidualnych członków zespołu. Największe znaczenie mają w fazie planowania projektu, gdyż zespół podlega wtedy tworzeniu, poprzez pozyskiwanie zasobów ludzkich, tj. prowadzone są pertraktacje z jego potencjalnym członkami i/lub ich przełożonymi, dotyczące zwłaszcza następujących kwestii:

- merytorycznego i czasowego zakresu zaangażowania w projekt,

- $\quad$ szczegółowego zakresu zadań, uprawnień i odpowiedzialności,

- wymaganego wkładu wiedzy, umiejętności i doświadczenia,

- relacji do innych członków zespołu i zasad współdziałania z nimi,

- wymagań wynikających z technik zarządzania, procedur, kultury organizacyjnej itp.,

- standardów produktywności i jakości oraz kryteriów oceny realizowanych działań,

- $\quad$ zasad przydzielania i wielkości świadczeń (płacy podstawowej, premii i innych).

Ustalenia te muszą być zgodne z ogólnymi warunkami realizacji, standardami i parametrami projektu odnowy, określonymi przez kierowników wraz ze zleceniodawcą. W efekcie dochodzi do zawarcia kontraktów (formalnych lub niepisanych) $\mathrm{z}$ wykonawcami projektu.

W fazie realizacji projektu negocjacje dotyczą zwłaszcza niezbędnych czynności koordynacyjnych, zapewniających realizację przyjętych ustaleń co do podstawowych parametrów projektu, a także rozwiązywanie problemów we współdziałaniu członków zespołu. Wreszcie w końcowej fazie projektu może zachodzić konieczność renegocjacji przyjętych ustaleń czy nawet ich weryfikacji po ustaleniu efektów projektu i ocenie rezultatów pracy członków zespołu. Ostatecznie następuje rozliczenie i zamknięcie zawartych wcześniej kontraktów.

\section{Konflikty w procesie negocjacji dla odnowy organizacji}

Zgodnie z ogólną interpretacją negocjacji (podaną w punkcie pierwszym) i cechami rozważanych negocjacji (zob. punkt trzeci) można je rozpatrywać w dwóch wymiarach, tj. kooperacji i konkurencji. Pierwszy określa zakres współdziałania wszystkich interesariuszy, przy koordynacji kierownictwa projektu odnowy, dla sprawnej jego realizacji i osiągania ich wspólnych celów. Drugi związany jest z występowaniem konfliktów pomiędzy nimi (rozbieżności ich celów), utrudniających realizację projektu.

Do najczęściej występujących, potencjalnych konfliktów tego rodzaju należą:

1. spory kompetencyjne pomiędzy różnymi szczeblami zarządzania w firmie, wynikające z niewłaściwego określenia zakresów odpowiedzialności, ich niejednoznaczności i/lub nakładania się na siebie, zwłaszcza w relacji jednostki funkcjonalne - zespoły projektowe, np. przy stosowaniu struktur zadaniowych lub macierzowych,

2. problemy we współpracy z otoczeniem (innymi firmami, klientami, dostawcami itp.), dotyczące warunków wzajemnej komunikacji, wymiany i podejmowania decyzji,
3. nieporozumienia z innymi zespołami (realizującymi projekty konkurencyjne), związane z ograniczonością zasobów, pełnieniem odmiennych funkcji itp.,

4. konflikty wewnątrz firmy wynikające $\mathrm{z}$ niewłaściwych mechanizmów współ-zawodnictwa przy realizacji projektów, np. nieprawidłowych (zbyt rygorystycznych) standardów, czy nieadekwatnych mechanizmów motywacyjnych,

5. napięcia wynikające ze złej jakości informacji w firmie i w relacjach zewnętrznych (braków, opóźnień, niedokładności itp.).

Zakres przedmiotowy tych konfliktów obejmuje kwestie wymienione $w$ tab. 2. Spory te wpływają na powstawanie problemów i rozbieżności wewnątrz zespołu projektowego (omówionych poniżej), gdyż narzucają konieczność podejmowania działań zapobiegających (zwłaszcza dodatkowych negocjacji) i zarazem zakłócających realizację rutynowych działań w ramach projektów odnowy. Skądinąd omawiane konflikty pozytywnie wpływają na wprowadzanie zmian usprawniających w firmie (związanych z realizacją projektów), pobudzając wykonawców i stymulując poszukiwanie nowych rozwiązań.

Warto także zwrócić uwagę na najważniejsze problemy negocjacji prowadzonych wewnątrz zespołu projektowego. Wymiar konkurencji dotyczy wszelkiego rodzaju konfliktów w zespole, przede wszystkim $w$ trakcie realizacji projektu, tj. związanych z występowaniem różnego rodzaju zakłóceń we współdziałaniu jego członków. Ten drugi specyficzny (i trudniejszy) rodzaj negocjacji $w$ zespole jest zorientowany na rozwiązywanie owych konfliktów. Powstają one zarówno z przyczyn obiektywnych, tj. zmian zewnętrznych warunków realizacji projektu, jak i subiektywnych, czyli zależnych od wykonawców. Rozważane konflikty mogą obejmować:

1. rozbieżności zadań i priorytetów realizowanych w nadzorowanym zespole,

2. napięcia spowodowane nowymi, nieprzewidzianymi i/lub pracochłonnymi zadaniami,

3. problemy powodowane przez nagłe przeszkody czy zagrożenia realizacji zadań,

4. napięcia wynikające z nierównomiernego obciążenia wykonawców pracą,

5. spory w związku z koniecznością dostępu do ograniczonych zasobów,

6. problemy z występowaniem opóźnień w realizacji zadań,

7. problemy koordynacji przy realizacji zadań (uzgodnień ich zakresu, terminów itp.),

8. rozbieżności w ocenie efektów pracy i wynagrodzenia,

9. spory powodowane przez orientację na działanie, ocenianie ludzi po czynach, a nie na podstawie ich spostrzeżeń, przemyśleń, uwag czy wątpliwości,

10. ścieranie się własnych, partykularnych interesów pracowników i ich grup,

11. różnice zdań, opinii czy poglądów między nimi,

12. narzucanie swoich opinii i sposobów pracy innym, przedmiotowe czy nawet instrumentalne traktowanie współpracowników, 
13. konflikty wynikające z różnic charakteru i osobowości członków zespołu, a także nawyków, spostrzeżeń i stereotypów w myśleniu i działaniu,

14. spory uwarunkowane nieformalnymi powiązaniami pomiędzy pracownikami.

\section{Podsumowanie}

Podsumowując, przedstawiona charakterystyka negocjacji w procesie odnowy organizacji stanowi użyteczne narzędzie identyfikacji i analizy tego rodzaju negocjacji na potrzeby realizacji projektów odnowy. Najistotniejsze zalety proponowanej koncepcji to uniwersalność i wielowymiarowość podejścia. Dotyczy bowiem wszelkiego rodzaju negocjacji dla odnowy organizacji oraz uwzględnia wszystkie istotne aspekty ich opisu i analizy (uwarunkowania, specyficzne cechy, poszczególne rodzaje, w tym uczestników, zakres i cele). Ponadto udało się wykazać, iż tak specyficzne przedsięwzięcie jak odnowa organizacji stanowi ważny obszar zastosowania negocjacji w firmie, a ich opis i analiza są istotnym przedmiotem badań i zastosowań.

Z drugiej jednak strony przedstawiona propozycja stanowi dopiero wstępne ujęcie negocjacji dla odnowy organizacji. Niezbędne jest bowiem jej rozwijanie (w ramach dalszych badań autora), głównie pod kątem konkretyzacji i operacjonizacji rodzajów omawianych negocjacji oraz wzbogacenia szczegółowych narzędzi metodycznych, ich identyfikacji i analizy. Powyższa koncepcja ma bowiem charakter uproszczony (modelowy). W praktyce negocjacje dotyczące projektów odnowy są złożone i wieloaspektowe oraz uwarunkowane specyfiką (rodzajem, celami, zakresem itp.) projektów, których dotyczą. Wymagana jest także empiryczna weryfikacja proponowanej koncepcji w badaniach porównawczych, dotyczących różnorodnych negocjacji w obszarze zarządzania projektami odnowy w firmie, zarówno typowych (powtarzalnych), jak i bezprecedensowych, o znaczeniu strategicznym.

\section{Literatura}

Alchian A.A., Demsetz H., 1972, Production, information costs, and economic organization, The American Economic Review, vol. 62, no 5 (December).

Barringer B.R., Harrison J.S., 2000, Walking a tightrope: Creating value through interorganizational relationships, Journal of Management, vol. 26, no 3 .

Bielski M., 2004, Podstawy teorii organizacji i zarzadzania, Wydawnictwo C.H. Beck, Warszawa.
Bełz G., 2012, Potencjał dostosowawczy w procesach odnowy przedsiębiorstw, Przegląd Organizacji, nr 11.

Brandenburger A., Nalebuff B.J., 1997, Co-Opetition: A Revolution Mindset that Combines Competition and Cooperation. The game theory strategy that's changing the game of business,

Russell Sage Foundation \& Princeton University Press, New York.

Cyfert Sz., 2012, Systemowy model organizacji: perspektywa procesów odnowy organizacyjnej, Prace Naukowe Uniwersytetu Ekonomicznego we Wrocławiu, nr 276 (Strategie i mechanizmy odnowy przedsiębiorstw).

Cyfert Sz., Bełz G., Wawrzynek Ł., 2014, Wpływ burzliwości otoczenia na efektywność procesów odnowy organizacyjnej, Organizacja i Kierowanie, $\operatorname{nr} 1 \mathrm{~A}$ (159).

Eisenhardt K.M., Galunic D.Ch., 2000, Coevolving. at last a way to make synergies work, Harvard Business Review, vol. 78, no 1 (January-February).

Elias A.A., Cavana R.Y., Jackson L.S., 2002, Stakeholder analysis for R\&D project management, R\&D Management, vol. 32, no 4.

Ertel D., 2005, Negocjacje jako źródło przewagi konkurencyjnej, [w:] Negocjacje i rozwiązywanie konfliktów, Wydawnictwo Helion, Gliwice.

Famielec J., 1992, Układy kooperacyjne $w$ gospodarce rynkowej. Doświadczenia, strategie, Akademia Ekonomiczna w Krakowie, Kraków.

Gierszewska G., Romanowska M., 2003, Analiza strategiczna przedsiębiorstwa, Państwowe Wydawnictwo Ekonomiczne, Warszawa.

Greenhalgh L., 1986, Managing conflict, Sloan Management Review, vol. 27, no 4 .

Kozina A., 2012, Planowanie negocjacji w przedsiębiorstwie, Wydawnictwo UEK, Kraków.

Lewicki R.J., Saunders D.M., Barry B., Minton J.W., 2005, Zasady negocjacji. Kompendium wiedzy dla trenerów i menedżerów, Dom Wydawniczy Rebis, Poznań.

McManus J., Schlumberger S., 2002, The influence of stakeholder values on project management, Management Services, vol. 46, no 6.

Nalepka A., Kozina A., 2007, Podstawy badania struktury organizacyjnej, Wydawnictwo Akademii Ekonomicznej w Krakowie, Kraków.

Pawlak M., 2006, Zarzadzanie projektami, Wydawnictwo Naukowe PWN, Warszawa.

Ring P.S., van de Ven A.H., 1994, Developmental processes of cooperative interorganizational relationships, Academy of Management Review, vol. 19 , no 1.

Rządca R., 2003, Negocjacje w interesach, PWE, Warszawa.

Trocki M., Grucza B., Ogonek K., 2003, Zarządzanie projektami, Państwowe Wydawnictwo Ekonomiczne, Warszawa.

Ury W., 1995, Odchodząc od NIE. Negocjowanie od konfrontacji do kooperacji, Państwowe Wydawnictwo Ekonomiczne, Warszawa. 